Original Research Article

\title{
Adherence to ARRIVE guidelines in animal research articles published in a National and International Pharmacology Journal
}

\author{
Jitendra H. Hotwani, Kiran R. Deshmukh*, Manthan N. Mehta
}

Department of Pharmacology, T. N. Medical College and B.Y.L. Nair Ch. Hospital (TNMC), Mumbai, Maharashtra, India

Received: 24 April 2017 Accepted: 19 May 2017

*Correspondence to:

Dr. Kiran R. Deshmukh, Email: drdeshmukhkiran@ gmail.com

Copyright: (C) the author(s), publisher and licensee Medip Academy. This is an openaccess article distributed under the terms of the Creative Commons Attribution NonCommercial License, which permits unrestricted noncommercial use, distribution, and reproduction in any medium, provided the original work is properly cited.

\begin{abstract}
Background: This study compares the adherence to Animal Research: Reporting of In Vivo Experiments (ARRIVE) guidelines in an Indian (IJP: Indian Journal of Pharmacology) and International journal (JPET: Journal of Pharmacology and Experimental Therapeutics).

Methods: All original animal studies published in IJP and JPET between January 2014 and September 2015 were downloaded manually and 100 articles were randomly chosen from each journal and analyzed using the ARRIVE guidelines checklist and checked for adherence.

Results: Most articles indicated the ethical statement (IJP- 96\%, JPET- 98\%). Steps taken to minimize effects of subjective bias in the study design were not mentioned in more than half the articles (IJP-50\%, JPET-37\%). Details of experimental animals were not adequately reported (IJP- 79\%, JPET-68\%). Details of animal housing (IJP-20\%, JPET-39\%) and husbandry (IJP-59\%, JPET-51\%) were poorly reported. Explanation of sample size calculation was mentioned in $2 \%$ and $1 \%$ articles in IJP and JPET. Statistical methods were well explained, yet the methods used to assess whether the data met the assumptions of the statistical approach was poorly reported.

Conclusions: The present study demonstrates relatively suboptimal reporting standards in animal studies published in IJP and JPET. Adherence to ARRIVE guidelines can be improved.
\end{abstract}

Keywords: Animal experiments, ARRIVE, Experimental pharmacology, Publication guidelines, Reporting research

\section{INTRODUCTION}

The decision whether an intervention should be assessed in clinical studies or trials depends on the results of precluding animal experiments. Preliminary evaluations of safety and efficacy of any new intervention are carried out as preclinical animal experiments. Once these parameters are validated, the intervention can move ahead in the drug discovery pipeline. In spite of the preliminary importance attached to animal experiments, they remain a source of constant debate all over the world. ${ }^{1-4}$ Animal research constantly faces criticism for its poor study design and inadequate statistical power. The results are often misinterpreted and cannot be reproduced most of the times. The impact and translation of this research to humans is also questioned. The foundation for future clinical studies is based on the findings of animal experiments, and thus poor designing and reporting of these studies may expose humans to unnecessary harm or danger. ${ }^{5}$ The low reproducibility of preclinical studies can be attributed to incomplete and unsatisfactory reporting of experimental details. Thus, reporting of experimental details forms an integral part of a welldesigned and well conducted research. A well-reported experimental research prevents duplication and saves animal life, money as well as time. ${ }^{6}$

\section{The animals in research}

Reporting In Vivo Experiments (ARRIVE) guidelines published in 2010 were developed to improve reporting standards of animal experimental research imparting 
transparency and accuracy to bioscience research reporting. This guideline is based on the CONSORT (consolidated standards of reporting trials) statement for reporting of clinical trials. The ARRIVE guidelines detail the minimum information that should be reported when using animals in a research study and include a 20 -item checklist. $^{7}$

Indian Journal of Pharmacology (IJP) and Journal of Pharmacology and Experimental Therapeutics (JPET) are leading, reputed, and internationally recognized journals in the field of pharmacology published from India and the United States of America respectively. ${ }^{8,9}$ A major part of the studies published in IJP and JPET is constituted by animal research. It was thus considered worthwhile to assess the adherence to ARRIVE guidelines in the reporting of published animal studies in these two reputed journals.

\section{METHODS}

All original animal studies published in IJP and JPET between January 2014 and September 2015 were downloaded manually from the website of the journals (www.ijp-online.com, www.jpet.aspetjournals.org). One hundred articles were randomly chosen from each journal by means of a computer-generated randomization table. Only original animal studies were included in the study. Short communications, research letters, letter to editors, case reports, review articles, any research articles involving human participants, and in-vitro experimental studies were not taken into account. A total of 200 articles (100 from each journal) were analyzed using the ARRIVE guidelines checklist and checked for adherence. ${ }^{10}$ Any discrepancies were resolved by reanalysis of studies. The data were summarized as numbers and percentages using Microsoft Excel (Version 2013). The adherence to ARRIVE guidelines in the two journals was statistically compared using Chi-square test. We used the traditional $P$ value of 0.05 as a measure of statistical significance. Graph Pad Instat version 3 was the software used for statistical analysis.

\section{RESULTS}

A total of 100 articles each from IJP and JPET were analyzed using the ARRIVE checklist. ${ }^{10}$ The results of the same are tabulated in Table 1.

\section{DISCUSSION}

In the present study, we focused on 200 original animal research articles published in IJP and JPET between January 2014 and September 2015.

In our study, we found that the completeness of these studies with respect to the ARRIVE guidelines was suboptimal. Furthermore, half the items in the ARRIVE checklist were poorly reported by more than half of the studies published in both the journals. We found that all published studies in both journals had a clearly defined objective. This could be the result of an editorial prerequisite to define the objectives of the study for submission of the paper. We found that more than $95 \%$ articles in both the journals provided a statement of ethics or provided information on animal welfare. Although it is clearly mentioned under "editorial policy" that "a statement on Ethics Committee permission and ethical practices must be included in all research articles under the "materials and methods' section," still 2-4\% of published studies did not report ethical clearance in both journals. Most studies did not explain how and why the said animal species and model were being used to address the scientific objectives and where appropriate its relevance to human biology was not reported. A time-line diagram or flow-chart can be useful to illustrate how complex study designs were carried out. However, none of the articles evaluated in the present study, in both the journals illustrated a flow diagram. The use of the term "can be" in the ARRIVE checklist, for this item, could be the reason for its omission by most authors. Though the methodology of the experimental procedures were well described, where the procedure was carried out was reported in less than 20 percent articles in both the journals.

The "why" of experimental procedures such as rationale for the choice of specific anaesthetic, route of administration, drug dose used were not reported in both the journals. Providing details of animals used in the study is important to ensure the validity and reproducibility of results. ${ }^{11}$ As compared to IJP (79\%), only $68 \%$ in JPET had mentioned details of animals used (species, sex, strain, developmental stage, weight). Information on the source of animal procurement, genetic nomenclature, health and immune status was reported in $63 \%$ articles in IJP and $78 \%$ articles in JPET; the difference being statistically significant. Housing $(20 \%$ articles in IJP and 39\% articles in JPET) and husbandry (59\% articles in IJP and 51\% articles in JPET) conditions were poorly reported and the comparison between the two journals viz. IJP and JPET showed statistical significance with respect to housing conditions. Details of any sample size calculation or explanation as to how the number of animals were arrived at were hardly reported. As is the case with clinical studies, the inadequate sample size may lead to an inability to find a significant difference between treatment groups. As such, conducting such type of underpowered studies may be regarded as unethical. ${ }^{11}$ One method to prevent this shortcoming at an early stage is to include a medical statistician into the existing Institutional Animal Ethics Committees. Statistical methods were well explained, yet the methods used to assess whether the data met the assumptions of the statistical approach was poorly reported. Random allocation of animals to different experimental groups has been recommended to ensure baseline comparability and to equally distribute any confounding factors (known or unknown). Randomization also eliminates selection bias. Blinding of 
the observer, in respect to which the animal belonged to which treatment group, is another method to eliminate the bias in results. However, this was poorly reported in both the journals. Baseline data for each experimental group, reporting of relevant characteristics and health status of animals (e.g. weight, microbiological status, and drug-or test naïve) prior to treatment or testing was not mentioned in any articles.

Table 1: Arrive guidelines adherence checklist.

\begin{tabular}{|c|c|c|c|c|c|}
\hline Item & Sub-item & No & & $\begin{array}{l}\text { IJP } \\
(n=100)\end{array}$ & $\begin{array}{l}\text { JPET } \\
(n=100)\end{array}$ \\
\hline Title & & 1 & $\begin{array}{l}\text { Provide as accurate and concise a description of the content of } \\
\text { the article as possible }\end{array}$ & 100 & 100 \\
\hline Abstract & & 2 & $\begin{array}{l}\text { Provide an accurate summary of the background, research } \\
\text { objectives, including details of the species or strain of animal } \\
\text { used, key methods, principal findings and conclusions of the } \\
\text { study. }\end{array}$ & 100 & 100 \\
\hline \multirow{3}{*}{ Introduction } & \multirow[t]{2}{*}{ Background } & $3 a$ & $\begin{array}{l}\text { a. Include sufficient scientific background (including relevant } \\
\text { references to previous work) to understand the motivation and } \\
\text { context for the study, and explain the experimental approach } \\
\text { and rationale. }\end{array}$ & 97 & 98 \\
\hline & & $3 b$ & $\begin{array}{l}\text { b. Explain how and why the animal species and model being } \\
\text { used can address the scientific objectives and, where } \\
\text { appropriate, the study's relevance to human biology. }\end{array}$ & 29 & 34 \\
\hline & Objectives & 4 & $\begin{array}{l}\text { Clearly describe the primary and any secondary objectives of } \\
\text { the study, or specific hypotheses being tested }\end{array}$ & 100 & 100 \\
\hline \multirow{14}{*}{ Methods } & Ethical statement & 5 & $\begin{array}{l}\text { Indicate the nature of the ethical review permissions, relevant } \\
\text { licences (e.g. Animal [Scientific Procedures] Act 1986), and } \\
\text { national or Institutional guidelines for the care and use of } \\
\text { animals, that cover the research. }\end{array}$ & 96 & 98 \\
\hline & \multirow{6}{*}{ Study design } & & $\begin{array}{l}\text { For each experiment, give brief details of the study design } \\
\text { including }\end{array}$ & & \\
\hline & & $6 a$ & a. The number of experimental and control groups. & 100 & 100 \\
\hline & & $6 b$ & $\begin{array}{l}\text { b. Any steps taken to minimize the effects of subjective bias } \\
\text { when allocating animals to treatment (e.g. randomisation } \\
\text { procedure) }\end{array}$ & 50 & 37 \\
\hline & & $6 c$ & $\begin{array}{l}\text { When assessing results (e.g. if done, describe who was blinded } \\
\text { and when) }\end{array}$ & 0 & 0 \\
\hline & & $6 d$ & $\begin{array}{l}\text { c. The experimental unit (e.g. a single animal, group, or cage } \\
\text { of animals). }\end{array}$ & 100 & 100 \\
\hline & & $6 e$ & $\begin{array}{l}\text { d. A time-line diagram or flow chart can be useful to illustrate } \\
\text { how complex study designs were carried out. }\end{array}$ & 0 & 0 \\
\hline & \multirow{4}{*}{$\begin{array}{l}\text { Experimental } \\
\text { procedures }\end{array}$} & $7 \mathrm{a}$ & $\begin{array}{l}\text { How (e.g. drug formulation and dose, site and route of } \\
\text { administration, anaesthesia and analgesia used } \\
\text { [including monitoring], surgical (procedure, method } \\
\text { of euthanasia). Provide details of any specialist equipment } \\
\text { used, including supplier(s). }\end{array}$ & 97 & 98 \\
\hline & & $7 \mathrm{~b}$ & When (e.g. time of day). & 69 & 74 \\
\hline & & $7 \mathrm{c}$ & c. Where (e.g. home cage, laboratory, water maze) & 15 & 19 \\
\hline & & $7 d$ & $\begin{array}{l}\text { d. Why (e.g. rationale for choice of specific anaesthetic, route } \\
\text { of administration, drug dose used) }\end{array}$ & 0 & 0 \\
\hline & \multirow{2}{*}{$\begin{array}{l}\text { Experimental } \\
\text { animals }\end{array}$} & $8 \mathrm{a}$ & $\begin{array}{l}\text { a. Provide details of the animals used, including species, } \\
\text { strain, sex, developmental stage (e.g. mean or median age plus } \\
\text { age range) and weight (e.g. mean or median weight plus } \\
\text { weight range) }\end{array}$ & 79 & 68 \\
\hline & & $8 b$ & $\begin{array}{l}\text { b. Provide further relevant information such as the source of } \\
\text { animals, international strain nomenclature, genetic } \\
\text { modification status (e.g. knock-out or transgenic), genotype, } \\
\text { health/immune status, drug or test naive, previous procedures, } \\
\text { etc. }\end{array}$ & $63^{*}$ & $78^{*}$ \\
\hline & $\begin{array}{l}\text { Housing and } \\
\text { husbandry }\end{array}$ & $9 a$ & $\begin{array}{l}\text { a. Housing (e.g. type of facility, e.g. specific pathogen free } \\
\text { [SPF]; type of cage or housing; bedding material; number of } \\
\text { cage companions; tank shape and material etc. for fish). }\end{array}$ & $20^{*}$ & $39^{*}$ \\
\hline
\end{tabular}




\begin{tabular}{|c|c|c|c|c|c|}
\hline Item & Sub-item & No & & $\begin{array}{l}\text { IJP } \\
(n=100)\end{array}$ & $\begin{array}{l}\text { JPET } \\
(\mathbf{n}=100)\end{array}$ \\
\hline & & $9 b$ & $\begin{array}{l}\text { b. Husbandry conditions (e.g. breeding programme, } \\
\text { light/dark cycle, temperature, quality of water etc. for fish, } \\
\text { type of food, access to food and water, environmental } \\
\text { enrichment). }\end{array}$ & 59 & 51 \\
\hline & & $9 c$ & $\begin{array}{l}\text { c. Welfare-related assessments and interventions that were } \\
\text { carried out prior to, during, or after the experiment. }\end{array}$ & 0 & 0 \\
\hline & & $10 \mathrm{a}$ & $\begin{array}{l}\text { a. Specify the total number of animals used in each } \\
\text { experiment and the number of animals in each } \\
\text { experimental group. }\end{array}$ & 91 & 93 \\
\hline & Sample size & $10 \mathrm{~b}$ & $\begin{array}{l}\text { b. Explain how the number of animals was arrived at. } \\
\text { Provide details of any sample size calculation used. }\end{array}$ & 2 & 1 \\
\hline & & $10 \mathrm{c}$ & $\begin{array}{l}\text { c. Indicate the number of independent replications of each } \\
\text { experiment, if relevant. }\end{array}$ & 0 & 0 \\
\hline & $\begin{array}{l}\text { Allocating } \\
\text { animals }\end{array}$ & $11 \mathrm{a}$ & $\begin{array}{l}\text { a. Give full details of how animals were allocated to } \\
\text { experimental groups, including randomisation or } \\
\text { matching if done }\end{array}$ & $50^{*}$ & $36^{*}$ \\
\hline & $\begin{array}{l}\text { to experimental } \\
\text { groups }\end{array}$ & $11 \mathrm{~b}$ & $\begin{array}{l}\text { b. Describe the order in which the animals in the different } \\
\text { experimental groups were treated and assessed }\end{array}$ & 100 & 100 \\
\hline & $\begin{array}{l}\text { Experimental } \\
\text { outcomes }\end{array}$ & 12 & $\begin{array}{l}\text { Clearly define the primary and secondary experimental } \\
\text { outcomes assessed (e.g. cell death, molecular markers, } \\
\text { behavioural changes). }\end{array}$ & 100 & 100 \\
\hline & & $13 \mathrm{a}$ & $\begin{array}{l}\text { a. Provide details of the statistical methods used for each } \\
\text { analysis }\end{array}$ & 99 & 100 \\
\hline & $\begin{array}{l}\text { Statistical } \\
\text { methods }\end{array}$ & $13 b$ & $\begin{array}{l}\text { b. Specify the unit of analysis for each dataset (e.g. single } \\
\text { animal, group of animals, single neuron). }\end{array}$ & 99 & 100 \\
\hline & & $13 \mathrm{c}$ & $\begin{array}{l}\text { c. Describe any methods used to assess whether the data } \\
\text { met the assumptions of the statistical approach. }\end{array}$ & 19 & 23 \\
\hline \multirow{6}{*}{ Results } & Baseline data & 14 & $\begin{array}{l}\text { For each experimental group, report relevant characteristics } \\
\text { and health status of animals (e.g. weight, microbiological } \\
\text { status, and drug- or test naive) prior to treatment or testing } \\
\text { (this information can often be tabulated). }\end{array}$ & 0 & 0 \\
\hline & \multirow[t]{2}{*}{ Numbers analysed } & $15 \mathrm{a}$ & $\begin{array}{l}\text { a. Report the number of animals in each group included in } \\
\text { each analysis. Report absolute numbers (e.g. 10/20, not } \\
50 \%^{2} \text { ). }\end{array}$ & 91 & 93 \\
\hline & & $15 b$ & $\begin{array}{l}\text { b. If any animals or data were not included in the analysis, } \\
\text { explain why }\end{array}$ & 0 & 0 \\
\hline & $\begin{array}{l}\text { Outcomes and } \\
\text { estimation }\end{array}$ & 16 & $\begin{array}{l}\text { Report the results for each analysis carried out, with a } \\
\text { measure of precision (e.g. standard error or confidence } \\
\text { interval). }\end{array}$ & $94^{*}$ & $83^{*}$ \\
\hline & \multirow{2}{*}{ Adverse events } & $17 \mathrm{a}$ & $\begin{array}{l}\text { a. Give details of all important adverse events in each } \\
\text { experimental group. }\end{array}$ & 0 & 0 \\
\hline & & $17 b$ & $\begin{array}{l}\text { b. Describe any modifications to the experimental } \\
\text { protocols made to reduce adverse events. }\end{array}$ & 0 & 0 \\
\hline \multirow{5}{*}{ Discussion } & \multirow{3}{*}{$\begin{array}{l}\text { Interpretation/ } \\
\text { scientific } \\
\text { implications }\end{array}$} & $18 \mathrm{a}$ & $\begin{array}{l}\text { a. Interpret the results, taking into account the study } \\
\text { objectives and hypotheses, current theory and other } \\
\text { relevant studies in the literature }\end{array}$ & 100 & 100 \\
\hline & & $18 b$ & $\begin{array}{l}\text { b. Comment on the study limitations including any } \\
\text { potential sources of bias, any limitations of the animal } \\
\text { model, and the imprecision associated with the results. }\end{array}$ & 84 & 88 \\
\hline & & $18 \mathrm{c}$ & $\begin{array}{l}\text { c. Describe any implications of your experimental methods } \\
\text { or findings for the replacement, refinement or } \\
\text { reduction (the 3Rs) of the use of animals in research }\end{array}$ & 0 & 0 \\
\hline & \multirow{2}{*}{$\begin{array}{l}\text { Generalisability/ } \\
\text { translation }\end{array}$} & 19 & $\begin{array}{l}\text { Comment on whether, and how, the findings of this study } \\
\text { are likely to translate to other species or systems, } \\
\text { including any relevance to human biology }\end{array}$ & 0 & 0 \\
\hline & & 20 & $\begin{array}{l}\text { List all funding sources (including grant number) and the } \\
\text { role of the funder(s) in the study. }\end{array}$ & $98^{*}$ & $88^{*}$ \\
\hline
\end{tabular}

${ }^{*} \mathrm{P}<0.05$, As obtained by Chi-Square Test 
Adverse events in the experimental groups were not reported in any of the published articles. Though the incidence of adverse events may not be too high, it is rather unlikely to say that no adverse events were reported. The ARRIVE guidelines are based on the principles of the 3Rs- replacement, refinement or reduction. ${ }^{10}$ The implications of the experimental methods on these principles were not described by any article. Animal research undergoes constant criticism with respect to its translatability and thus commenting on whether and how the findings of this study are likely to translate to other species or systems, including any relevance to human biology adds more credibility to the research. Unfortunately, none of the studies had any comment on the generalizability or translation potential of their study.

A statistical comparison with respect to the reporting standards shows a significant difference between the two journals, with IJP faring better than JPET in most parameters except source of animal procurement, disease status viz. other relevant information on experimental animals and housing standards. The author guidelines for both these journals clearly state that in vivo animal research should be reported in accordance with ARRIVE guidelines only. In spite of this, the adherence is not optimum in both the journals.

The present study takes into consideration only two journals and articles published in them over a period of one year. This could be a limitation of the present study. However, to the best of our knowledge, this is the first assessment of a comparison between animal research articles published in an Indian and an international pharmacology journal. Thus, this could provide future insights as adherence to standard guidelines should be routinely evaluated.

\section{CONCLUSION}

The present study demonstrates relatively suboptimal reporting standards in animal studies published in IJP and JPET. The knowledge shared in the present paper could be used for better reporting of animal-based experiments. There is a need of enhancing awareness of ARRIVE guidelines among researchers as well as editors concerned with animal experiments. Editors are in a unique position to improve manuscripts in this regard. Incomplete information should not be published. A checklist of essential information of any experiment based study should be provided to the author or to be uploaded at the journal website along with other publishing guidelines.

Funding: No funding sources Conflict of interest: None declared

\section{Ethical approval: Not required}

\section{REFERENCES}

1. Hartung T. Look back in anger- What clinical studies tell us about preclinical work. ALTEX. 2013;30(3):275-91.

2. Dikshit RK. Animal experiments: Confusion, contradiction, and controversy. Indian $\mathrm{J}$ Pharmacol. 2012;44(6):661-62.

3. Pound P, Ebrahim S, Sandercock P, Bracken MB, Roberts I and Reviewing Animal Trials Systematically (RATS) Group. Where is the evidence that animal research benefits humans? BMJ. 2004 Feb 28;328(7438):514-7.

4. Van der Worp HB, Howells DW, Sena ES, Porritt MJ, Rewell S, O'Collins V, et al. Can animal models of disease reliably inform human studies? PLoS med. 2010 Mar 30;7(3):e1000245.

5. Baker D, Lidster K, Sottomayor A, Amor S. Two years later: Journals are not yet enforcing the ARRIVE guidelines on reporting standards for pre-clinical animal studies. PLoS Biol. 2014;12(1):e1001756.

6. Kilkenny C, Parsons N, Kadyszewski E, Festing MFW, Cuthill IC, Fry D, et al. Survey of the quality of experimental design, statistical analysis and reporting of research using animals. PLoS One. 2009;4(11):e7824.

7. Kilkenny C, Browne WJ, Cuthill IC, Emerson M, Altman DG. Improving bioscience research reporting: the ARRIVE guidelines for reporting animal research. PLoS Biol. 2010;8(6):e1000412.

8. Indian Journal of Pharmacology. Available at: http://www.ijp-online.com. Accessed 10 April 2017.

9. Journal of Pharmacology and Experimental Therapeutics. Available at: http://www.jpet.aspetjournals.org. Accessed 10 April 2017.

10. The ARRIVE Guidelines Checklist - NC3Rs. Available at: https://www.nc3rs.org.uk/sites/default/files/document s/Guidelines/NC3Rs\%20ARRIVE\%20Guidelines\%2 0Checklist\% 20(fillable).pdf. Accessed 10 April 2017.

11. McCance I. Assessment of statistical procedures used in papers in the Australian Veterinary Journal. Aust Vet J. 1995;72(9):322-8.

Cite this article as: Hotwani JH, Deshmukh KR, Mehta MN. Adherence to ARRIVE guidelines in animal research articles published in a National and International Pharmacology Journal. Int J Basic Clin Pharmacol 2017;6:1696-700. 